\title{
Investigation of the Relationship between Digital Citizenship and Digital Literacy Levels of Secondary School Students
}

\author{
Mustafa Kaya \\ Harran County National Education, Harran, Sanliurfa, Turkey \\ E-mail: mstfa.kya42@gmail.com \\ Gulriz Imer \\ Department of Computer Education and Instructional Technologies, \\ Mersin University, Mersin, Turkey \\ E-mail: gulrizimer@gmail.com
}

\begin{abstract}
The main purpose of this study is to determine whether digital literacy is a predictor of digital citizenship by examining the relationship between digital citizenship and digital literacy levels of secondary education students in terms of various variables. The study group of the study consists of 847 secondary school students' who study in public schools in Selcuklu central district of Konya province in 2018 - 2019 academic year. The screening method, one of the quantitative research methods, was used in the research. As data collection tool; "Personal Information Form" developed by the researcher to reach the personal information of secondary school students, "Digital Citizenship Scale" developed by Som-Vural to determine the levels of digital citizenship, and "Digital Literacy Scale" developed by Hamutoglu and others to determine the levels of digital literacy was applied. At the end of the study, it was concluded that the digital citizenship levels of secondary school students were high. It was concluded that there is a significant difference between the levels of digital citizenship of secondary school students and the year of internet use. It is concluded that there was no significant difference between gender, class level, time spent on daily internet time variables and secondary school students' digital literacy levels. There was no significant difference between class level variable and digital literacy level. In the correlation analysis conducted to determine the relationship between digital citizenship levels and digital literacy levels of secondary school students, it was found that there was a positive directional and significant relationship at the, medium-level. In addition, the effect of digital literacy on digital citizenship was found to be positive directional and significant.
\end{abstract}

Keywords: Digital citizenship, digital literacy, secondary school students, survey.

DOI: $10.7176 /$ JSTR/6-12-02

\section{Ortaöğretim Öğrencilerinin Dijital Vatandaşlık ve Dijital Okuryazarlık Düzeyleri Arasındaki İlişkinin İncelenmesi}

\begin{abstract}
Özet
Araştırmanın temel amacı, ortaöğretim öğrencilerinin dijital vatandaşlık ve dijital okuryazarlık düzeyleri arasındaki ilişkinin çeşitli değişkenler açısından incelenerek, dijital okuryazarlığın dijital vatandaşlı̆̆ın yordayıcısı olup olmadığını belirlemektir. Araştırma grubunu 2018 - 2019 eğitim öğretim yılında Konya ili Selçuklu ilçesi devlet okullarında öğrenim öğren 847 ortaöğretim öğrencileri oluşturmaktadır. Araştırmada nicel araştırma yöntemlerinden tarama yöntemi kullanılmış̧ır. Veri toplama aracı olarak; araştırmacı tarafından geliştirilen "Kişisel Bilgi Formu", dijital vatandaşlık düzeylerinin belirlemede Som-Vural tarafindan geliştirilen "Dijital Vatandaşlık Ölçeği" ve dijital okuryazarlık düzeylerinin belirmek için ise Hamutoğlu ve diğerleri tarafindan geliştirilen "Dijital
\end{abstract}

9| P a g e

www.iiste.org 
Okuryazarlık Ölçeği” kullanılmıştır. Araştırma sonunda, ortaöğretim öğrencilerinin dijital vatandaşlık düzeylerinin yüksek olduğu sonucuna varılmıştır. Ortaöğretim öğrencilerinin dijital vatandaşlık düzeyleri ile internet kullanım yılı değişkeni arasında anlamlı farklılı̆̆ın olduğu, cinsiyet, sınıf düzeyi, günlük internette harcanan süre değişkenleri ile dijital vatandaşlık düzeyi arasında anlamlı bir farklılık olmadığ 1 görülmüsşür. Ortaöğretim öğrencilerinin dijital okuryazarlık düzeylerinin yüksek olduğu sonucuna varılmıştır. Ortaöğretim öğrencilerinin dijital okuryazarlık düzeyleri ile cinsiyet, internet kullanım yılı ve günlük internette harcanan süre değişkenleri arasında anlamlı farklılı̆̆ı olduğu sonucuna ulaşılmıştır. Sınıf düzeyi değiş̧eni ile dijital okuryazarlık düzeyi arasında anlamlı bir farklılık görülmemiştir. Ortaöğretim öğrencilerinin dijital vatandaşlık düzeyleri ile dijital okuryazarlık düzeyleri arasındaki ilişkiyi belirlemek üzere yapılan korelasyon analizinde, orta düzeyde, pozitif yönlü ve anlamlı bir ilişki olduğu bulunmuştur. Ayrıca, dijital okuryazarlı̆̆ın dijital vatandaşlık üzerindeki etkisi pozitif yönlü ve anlamlı bulunmuştur.

Anahtar Kelimeler: Dijital vatandaşlık, dijital okuryazarlık, ortaöğretim öğrencileri, tarama yöntemi

\section{Giriș}

Teknolojide son yıllarda meydana gelen hızlı ve köklü değişimler birçok kişiyi etkilemektedir. Özellikle internet kullanımının her yaş grubu için önemli hale geldiği ve bireylerin yaşam biçimlerini de belirgin bir şekilde değiştirdiği görülmektedir. Teknolojilerin gelişmesiyle beraber internet, günlük yaşamımızın önemli bir parçası haline gelmiştir (Akkoyunlu ve Yılmaz, 2005). Bu durum özellikle yeni nesil öğrencilerde daha kolay ve hızlı bir şekilde ilerlemektedir. Teknolojideki çoklu değişimler dijital araçların üretilmesine ve bireylerin bu araçlar ile etkileşimini artırmaktadır. Bazen teknoloji bireyler için yarar sağlarken bazen de onlar için zararlı hale gelebilmektedir. Dijital ortamlarda bulunan bireyler, çevrimiçi hırsızlık, dolandırılma, yanlış yönlendirilme, siber zorbalık, kişisel bilgilerin paylaşımı, zararlı yazılımlar, istismar vb. istenmeyen davranışlara karşı karşıya kalabilmektedir (TİB, 2012). Bu durum bireylerin teknolojiyi ne şekilde kullandığı ile ilgilidir. Bireyler bir sorunla karşılaştığı zaman teknolojinin onlara ne derece çözüm üretebildiği önemli bir noktadır. Bu nedenle teknolojiye ve bilgiye yüklenen anlam açısından yaş önemli bir değişken haline getirmiştir. Teknolojideki bu gelişmeler öyle hızlı bir şekilde meydana gelmiş ki, neredeyse bir kuşak doğduğu andan itibaren teknolojiyle tanışrken başka bir kuşak ise, teknolojiyi ancak yirmili yaş ve sonrasında tanışabilmiştir. Yaş ve teknoloji etkileşimini ilk kez Prensky (2001) "dijital yerli" ve "dijital gö̧̧men" olmak üzere iki temel kavramdan söz etmiştir.

Dijital yerli, teknoloji temelli bir dünyaya doğan ve çok küçük yaşlardan itibaren teknolojiyle tanışarak, kendilerine teknolojik bir öğrenme dili geliştiren yeni nesil öğrencilere dijital yerliler denilmektedir (Prensky, 2001). Dijital yerli olarak ifade ettiğgimiz yeni nesil öğrenciler interneti günlük yaşamlarının bir parçası haline getirmiştir. Hane Halkı Bilişim Teknolojileri Kullanım Araştırması raporuna bakıldığında interneti en yoğun olarak kullananlar arasında 16-24 yaş aralığı bulunmaktadır (TÜiK, 2019). Dijital ortamda gerçekleştirilen eylemlerde etik davranmak, güvenlik önlemleri almak, karşılaşılabilecek her türlü olumlu ya da olumsuz duruma karşı hazırlıklı olmak, dijital ortam kullanıcılarının dikkat etmesi gereken konular olarak karşımıza çıkmaktadır (Som-Vural ve Kurt, 2017). Bu konuları yaşamının bir parçası haline getiren bireyler için dijital vatandaşlık kavramını gündeme gelmektedir.

Dijital vatandaşılı; bilgi ve iletişim kaynaklarını kullanırken eleştirebilen, dijital ortamda yapılan davranışların etik sonuçlarının farkında olan, teknolojiyi başkalarına zarar vermeyecek şekilde kullanabilen, internet ortamında iletişim hakkını kullanan, yaptığı paylaşımlarında ve işbirliğinde doğru tutumu sergileyen ve başkalarını da buna yönelten bireylerdir (Çubukçu ve Bayzan, 2013). Bir başka deyişle dijital vatandaşlığın, bilgi ve iletişim teknolojilerinin yasal, güvenli, etik ve sorumlu bir biçimde kullanımını sağlayan davranışları çevrimiçi ortamda uygulamak olduğu belirtilmiştir (ISTE, 2007). Dijital vatandaşlık kavramının içerisinde pek çok alt boyut yer almaktadır. Dijital vatandaşlık boyutları dijital etik, dijital iletişim, dijital okuryazarlık, dijital erişim, dijital ticaret, dijital hukuk, dijital güvenlik, dijital hak ve sorumluluk ve dijital sağlık şeklinde belirlenmiş ve kabul görmüştür (Ribble, 2007).

Dijital vatandaşlık, teknolojiyi amaçlarına uygun kullanmayla ilgili ilkeleri temel alırken, dijital okuryazarlık ise, dijital vatandaşlığın en önemli alt boyutlarında olan (Ribble, 2011) dijital ortamlarda kişilerin sahip olması gereken becerilerin tamamını kapsamaktadır. Dijital vatandaşlı̆̆ın genç bir yaşta öğretilmesinin gerekliliği, hem eğitimcilerde, hem de idarecilerde dijital vatandaşlık bilincinin

$10 \mid \mathrm{P}$ a g e

www.iiste.org 
arttırılmasının ve teknolojinin yanlış kullanımına karşı sürekli önlem alınmasının önemi göz ardı edilmemelidir (Hollandsworth, Donovan ve Welch, 2017).

Araştırmanın amacı, ortaöğretim öğrencilerinin dijital vatandaşlık ve dijital okuryazarlık düzeyleri arasındaki ilişkinin çeşitli değişkenler açısından incelenerek, dijital okuryazarlık dijital vatandaşlı̆̆ın yordayıcısı olup olmadığını belirlemektir. Teknolojiyle iç içe yaşayan yeni nesil öğrencilerin dijital ortam ve araçları kullanırken ne kadar bilinçli olduklarının ve toplumda iyi bir dijital vatandaş ve dijital okuryazar olarak yaşamlarını sürdürüp sürdürmediklerinin ortaya konabileceği bu araştırma doğrultusunda aşağıdaki sorulara yanıt aranması amaçlanmıştır.

1. Ortaöğretim öğrencilerinin dijital vatandaşlık düzeyleri nedir?

2. Ortaöğretim öğrencilerinin dijital vatandaşlık düzeyleri;

- Cinsiyet,

- Sinıf düzeyi,

- İnternet kullanım yıl1,

- Günlük internette harcanan süre bakımından anlamlı bir farklılık göstermekte midir?

3. Ortaöğretim öğrencilerinin dijital okuryazarlık düzeyleri nedir?

4. Ortaöğretim öğrencilerinin dijital okuryazarlık düzeyleri;

- Cinsiyet,

- Sinıf düzeyi,

- İnternet kullanım yıll,

- Günlük internette harcanan süre bakımından anlamlı bir farklılık göstermekte midir?

5. Ortaöğretim öğrencilerinin dijital vatandaşlık ile dijital okuryazarlık düzeyleri arasında anlamlı bir ilişki var mıdır?

6. Dijital okuryazarlık dijital vatandaşlığın yordayıcısı mıdır?

\section{Yöntem}

\subsection{Araștırmanın Modeli}

Ortaöğretim öğrencilerinin dijital vatandaşlık ve dijital okuryazarlık düzeylerinin çeşitli değişkenler açısından inceleyip, dijital vatandaşlık ile dijital okuryazarlık düzeyleri arasındaki ilişkiyi belirlemeyi amaçlayan bu araştırma da tarama yöntemi kullanılmıştır. Bu araştırmada, ortaöğretim öğrencilerinin dijital vatandaşlık ve dijital okuryazarlık düzeyleri arasındaki ilişskinin incelenmesi amaçlandığından, iki veya daha fazla değişken arasında birlikte değişimi veya dereceyi belirleyen ilişkisel tarama modeline göre düzenlenmiştir.

\subsection{Evren ve Örneklem}

Araştırmanın çalışma evrenini, 2018-2019 eğitim-öğretim yılında, Konya ili Selçuklu ilçesinde bulunan toplam 27.692 ortaöğretim öğrencisi oluşturmaktadır. Bu evren üzerinden seçkisiz olmayan örneklem tiplerinden amaçsal örneklem kullanılarak araştırmanın örneklem sayısı belirlenmiş̧ir. Amaçsal örneklem tiplerinden ise, maksimum çeşitlilik örnekleme (maximum variation sampling) kullanılmıştır (Büyüköztürk ve diğerleri 2016). Konya ili Selçuklu ilçesinde bulunan sosyo-ekonomik düzeyi yüksek olan bir ortaöğretim kurumu; sosyo-ekonomik düzeyi orta olan bir ortaöğretim kurumu; sosyoekonomik düzeyi alt olan iki ortaöğretim kurumu belirlenerek örneklem seçimi yapılmıştır. Belirlenen ortaöğretim kurumları içinde öğrenim gören toplam 847 öğrenci örneklem olarak belirlenmiştir. Araştırmaya katılan ortaöğretim öğrencilerinin cinsiyetine, sınıf düzeylerine, internet kullanım yıllarına ve günlük internette harcanan süreye göre sayısal dağılımları ve yüzdeleri Tablo 1'de sunulmaktadır. 
Tablo 1. Öğrencilerin belirlenen değişkenlere göre sayısal dağılımları ve yüzdeleri

\begin{tabular}{|c|c|c|c|}
\hline Değişkenler & & $\mathbf{N}$ & $\%$ \\
\hline \multirow{2}{*}{ Cinsiyet } & $\mathrm{K} 1 \mathrm{z}$ & 522 & 61,6 \\
\hline & Erkek & 325 & 38,4 \\
\hline \multirow{4}{*}{ Sınıf Düzeyleri } & 9. Sinif & 294 & 34,7 \\
\hline & 10. Sinif & 244 & 28,8 \\
\hline & 11. Sinıf & 182 & 21,5 \\
\hline & 12. Sinif & 127 & 15,0 \\
\hline \multirow{4}{*}{$\begin{array}{c}\text { İnternet Kullanım } \\
\text { Yılları }\end{array}$} & 1 yıldan az & 14 & 1,7 \\
\hline & $1-2$ y1l & 61 & 7,2 \\
\hline & $2-5$ yil & 283 & 33,4 \\
\hline & 5 yıldan fazla & 489 & 57,7 \\
\hline \multirow{4}{*}{$\begin{array}{l}\text { Günlük İnternette } \\
\text { Harcanan Süre }\end{array}$} & 1 saatten az & 94 & 11,1 \\
\hline & 1 - 2 saat & 310 & 36,6 \\
\hline & 2 - 5 saat & 350 & 41,3 \\
\hline & 5 saatten fazla & 93 & 11,0 \\
\hline
\end{tabular}

Tablo 1 incelendiğinde, öğrencilerin \%61,6 oranında kı, \%38,4'unun erkek olduğu, \%34,7'sının 9.sınıf, $\% 28,8^{\prime}$ 'inin 10.sınıf, $\% 21,5$ 'inin 11.sınıf, $\% 15^{\prime}$ 'i ise 12 .sınıf olduğu, öğrencilerin $\% 1,7$ 'si 1 yıldan az, \%7,2'si 1-2 yı1, \%33,4'ü 2-5 yı1, \%57,7'si ise 5 yıldan fazla internet kullanmış olduğu, \%11,1'i 1 saatten az, \%36,6'sini 1 - 2 saat , \%41,3 'ü 2-5 saat, \%11'inin ise 5 saatten fazla internette zaman harcadığı görülmektedir.

\subsection{Veri Toplama Aracı}

Araştırma verileri, 3 farklı bölümden oluşan bir ölçme aracı ile toplanılmıştır. Birinci bölümde araştırmacı tarafından hazırlanan "Kişisel Bilgi Formu" kullanılmıştır. Kişisel Bilgi Formunda ortaöğretim öğrencilerinin cinsiyet, sınıf düzeyi, kaç yıldır internet kullandığı, bir günde internette harcadığ1 süreyi içeren toplam 4 soru yer almıştır. İkinci bölümde Som Vural (2016) tarafindan geliştirilen 23 maddeden oluşan "Dijital Vatandaşlık Ölçeği” kullanılmıştır. Ölçeğin Cronbach Alpha güvenirlik katsayısı .79 olarak hesaplanmıştır. Üçüncü bölümde Hamutoğlu ve diğerleri (2017) tarafından geliştirilen 17 maddeden oluşan "Dijital Okuryazarlık Ölçeği” kullanılmıştır. Ölçeğin Cronbach Alpha güvenirlik katsayısı .70 olarak hesaplanmıştır.

\subsection{Verilerin Toplanması}

Araştırma verileri 2018 - 2019 eğitim öğretim yılında Konya ili Selçuklu ilçesindeki devlet okullarında öğrenim gören ortaöğretim öğrencilerine uygulanan "Dijital Vatandaşlık” ve "Dijital Okuryazarlık" ölçme araçları aracılığıyla elde edilmiştir. Veri toplama sürecinde gerçekleştirilen adımlar Şekil 1' de yer almaktadır.
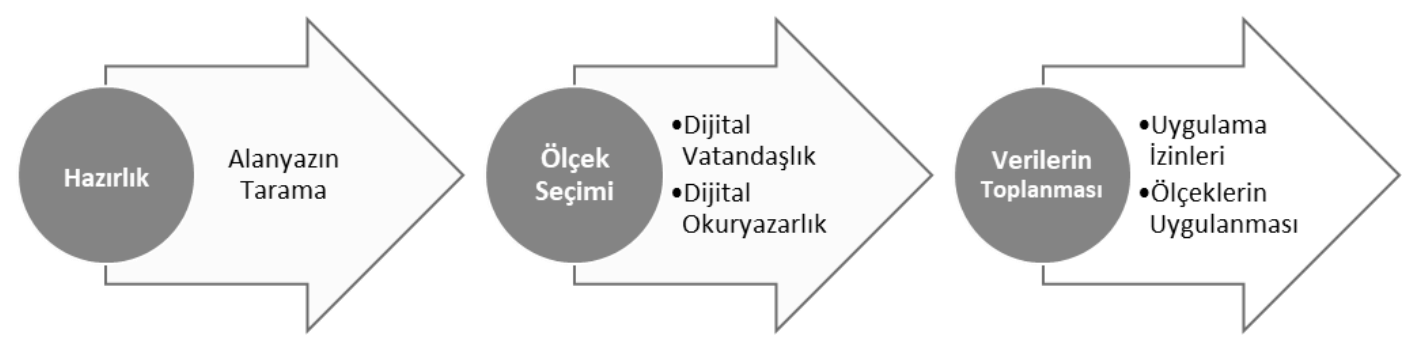

Şekil 1. Araştırmanın veri toplama süreçlerinin aşamaları 
Şekil 1'de görüldüğü gibi araştırmada öncelikle alanyazın taraması yapılarak dijital vatandaşlık ve dijital okuryazarlık ile ilgili yurt içinde ve yurt dışında yapılıış çalışmalar incelenmiştir. Bu doğrultuda geçerliği ve güvenirliği sağlanmış olan Som-Vural (2016) tarafindan geliştirilen "Dijital Vatandaşlık Ölçeği” ve Hamutoğlu ve diğerleri (2017) tarafından geliştirilen “Dijital Okuryazarlık Ölçeği” gerekli izinler alınarak ölçek seçimi gerçekleştirilmiştir. Uygulama ölçekleri çoğaltılmasıyla sınıf ortamında araştırmacı tarafından gerçekleştirilmiş ve öğrencilerin bu çalışmaya gönüllü katılımı esas alınmıştır. Uygulama yaklaşık olarak 25 - 30 dakika sürmüştür.

\subsection{Verilerin Analizi}

Araştırmaya katılımı sağlanan ortaöğretim öğrencilerinin dijital vatandaşlık ve dijital okuryazarlık düzeylerini belirlemek için betimsel analiz teknikleri (ortalama, standart sapma, en yüksek ve en düşük değerler) kullanılmıştır. Araştırma kapsamında, dijital vatandaşlık ve dijital okuryazarlık ölçeklerinden elde edilen puanları; cinsiyet, sınıf, internet kullanım süresi (yıl) ve günlük internet kullanım süresi değişkenlerine göre karşılaştırmak ve incelemek için ise, parametrik analiz teknikleri(T test, Anova) kullanılmıştır (Tablo 2). Araştırmada, dijital okuryazarlığın dijital vatandaşlık üzerindeki etkisini belirlemek için basit doğrusal regresyon analizi de gerçekleştirilmiştir. Veriler, IBM SPSS Statistics 25.0 paket programı kullanılarak analiz edilmiştir.

Tablo 2. Bağımlı, Bağımsız Değişkenler ve Uygulanan Analiz Teknikleri

\begin{tabular}{cll}
\hline Bağımı Değişken & Bağımsız Değişken & Analiz Tekniği \\
\hline & Cinsiyet & Bağımsız örneklem T testi \\
$\begin{array}{c}\text { Dijital Vatandaşlık ve } \\
\begin{array}{c}\text { Dijital Okuryazarlık } \\
\text { Ölçeklerinden Elde } \\
\text { Edilen Puanlar }\end{array}\end{array}$ & Sınıf & Tek yönlë varyans analizi (ANOVA) \\
& Günlük internet kullanım süresi & Tek yönlü varyans analizi (ANOVA) \\
\hline
\end{tabular}

\section{Bulgular}

\subsection{Birinci Alt Probleme İlişkin Bulgular}

Bu bölümde "Ortaöğretim öğrencilerinin dijital vatandaşlık düzeyleri nedir?" alt problemine ilişkin bulguya yer verilmiştir.

Tablo 3. Dijital Vatandaşlık Düzeyleri

\begin{tabular}{lllllll}
\hline Değişken & N & Minimum & Maksimum & $\bar{X}$ & Ss & Düzey \\
\hline $\begin{array}{l}\text { Dijital } \\
\text { Vatandaşlık }\end{array}$ & 847 & 2,52 & 5,00 & 3,99 & 0,44 & Yüksek \\
\hline
\end{tabular}

Tablo 3 incelendiğinde, ortaöğretim öğrencilerinin dijital vatandaşlık puanlarının 2,52 ile 5,00 arasında değiştiği anlaşılmaktadır. Ortaöğretim öğrencilerinin dijital vatandaşlık puan ortalaması 3,99 $(\mathrm{Ss}=0,44)$ olarak hesaplanmıştır. Elde edilen bu değer, araştırmaya katılan ortaöğretim öğrencilerinin dijital vatandaşlik düzeylerinin yüksek olduğunu göstermiştir.

\section{2. İkinci Alt Probleme İlişkin Bulgular}

Bu bölümde "Ortä̈ğretim ögrencilerinin dijital vatandaşlık düzeyleri; cinsiyetlerine, sinıf düzeylerine, internet kullanım yılına, günlük internette harcanan süre bakımından anlamlı bir farklılı göstermekte midir?" alt problemine ilişkin bulguya yer verilmiştir. 
Tablo 4. Dijital Vatandaşlık Ölçeğinden Alınan Puanların Cinsiyete Göre Karşılaştırılması

\begin{tabular}{lllllll}
\hline Değişken & Cinsiyet & $\mathbf{N}$ & $\overline{\boldsymbol{X}}$ & Ss & $\mathbf{t}$ & $\mathbf{p}$ \\
\hline \multirow{2}{*}{ Dijital Vatandaşlık } & Erkek & 325 & 3,97 &, 46 & & \\
& K1z & 522 & 4,00 &, 43 & & \\
\hline
\end{tabular}

Tablo 4 incelendiğinde, ortaöğretim öğrencilerinin dijital vatandaşlık puan ortalamalarının cinsiyete göre farklılaşıp farklılaşmadığına ilişkin yapılan bağımsız gruplar $\mathrm{t}$ testi sonuçlarına göre istatistiksel olarak anlamlı bir farklılık göstermediği anlaşılmaktadır $(\mathrm{p}>0,05)$.

Tablo 5. Dijital Vatandaşlık Ölçeğinden Alınan Puanların Sınıf Düzeylerine Göre Karşılaştırılması

\begin{tabular}{lllllll}
\hline Değişken & Sinıf & $\mathbf{N}$ & $\overline{\boldsymbol{X}}$ & Ss & $\mathbf{F}$ & $\mathbf{p}$ \\
\hline & 9. Sınıf & 294 & 3,98 &, 46 & & \\
& 10. Sınıf & 244 & 3,99 &, 45 & & \\
$\begin{array}{l}\text { Dijital } \\
\text { Vatandaşlık }\end{array}$ & 11. Sinıf & 182 & 3,99 &, 44 & 0,14 & \\
& 12. Sinıf & 127 & 4,01 &, 39 & \\
\hline
\end{tabular}

Tablo 5 incelendiğinde, ortaöğretim öğrencilerinin dijital vatandaşlık puan ortalamalarının sınıf düzeyine göre farklılaşıp farklılaşmadığına ilişkin yapılan Anova testi sonuçlarına göre gruplar arasında anlamlı bir fark görülmemektedir $(p>0,05)$. Araştırmaya katılan $9,10,11$ ve 12 . sinıf öğrencilerinin dijital vatandaşlık düzeylerinin aynı olduğunu anlaşılmıştır.

Tablo 6. Dijital Vatandaşlık Ölçeğinden Alınan Puanların İnternet Kullanım Yılına Göre Karşılaştırılması

\begin{tabular}{|c|c|c|c|c|c|c|c|}
\hline Değişken & Yıl & $\mathbf{N}$ & $\overline{\boldsymbol{X}}$ & Ss & $\mathbf{F}$ & $\mathbf{p}$ & Fark \\
\hline \multirow{4}{*}{ Dijital Vatandaşlık } & 1 yıldan az & 14 & 3,85 & ,42 & \multirow{4}{*}{3,63} & \multirow{4}{*}{0,01} & \multirow{4}{*}{$\begin{array}{l}2>1 ; \\
4>1 ;\end{array}$} \\
\hline & $1-2$ y1l & 61 & 4,03 & ,41 & & & \\
\hline & $2-5$ y1l & 283 & 3,93 & ,45 & & & \\
\hline & 5 yildan fazla & 489 & 4,03 & ,44 & & & \\
\hline
\end{tabular}

Tablo 6 incelendiğinde, ortaöğretim öğrencilerinin dijital vatandaşlık puan ortalamalarının internet kullanım yılına göre farklılaşıp farklılaşmadığına ilişkin yapılan Anova testi sonuçlarına göre gruplar arasında anlamlı bir farklılık gösterdiği anlaşılmaktadır $(\mathrm{p}<0,05)$. Grup farklılıklarının kaynağını belirlemek için Scheffe çoklu karşılaştırma testi kullanılmıştır. İnterneti "1-2 yıl" ve "5 yıldan fazla" kullandığını belirten öğrencilerin dijital vatandaşlık düzeyleri, interneti "1 yıldan az" kullandığını belirten öğrencilerden anlamlı olarak daha yüksek bulunmuştur. 
Tablo 7. Dijital Vatandaşlık Ölçeğinden Alınan Puanların Günlük İnternette Harcanan Süreye Göre Karşılaştırılması

\begin{tabular}{lllllll}
\hline Değişken & Günlük & $\mathbf{N}$ & $\overline{\boldsymbol{X}}$ & Ss & F & p \\
\hline \multirow{3}{*}{ Dijital } & 1 saatten az & 94 & 3,94 &, 44 & & \\
Vatandaşlik & $1-2$ saat & 310 & 4,01 &, 44 & \multirow{2}{*}{, 54} & 0,20 \\
& 2-5 saat & 350 & 4,01 &, 43 & & \\
& 5 saatten fazla & 93 & 3,92 &, 49 & & \\
\hline
\end{tabular}

Tablo 7 incelendiğinde, ortaöğretim öğrencilerinin dijital vatandaşlık puan ortalamalarının günlük internette harcanan süreye göre farklılaşıp farklılaşmadığına ilişkin yapılan Anova testi sonuçlarına göre gruplar arasında anlamlı bir farklılık göstermediği anlaşılmaktadır ( $p>0,05)$. Öğrencilerin günlük internet kullanım sürelerinin farklı olmasına karşın dijital vatandaşlık düzeylerinin aynı olduğunu anlaşılmıştır.

\section{3. Üçüncü Alt Probleme İlişkin Bulgular}

Bu bölümde "Ortä̈ğretim öğrencilerinin dijital okuryazarlık düzeyleri nedir?” alt problemine ilişkin bulguya yer verilmiştir.

Tablo 8. Dijital Okuryazarlık Düzeyleri

\begin{tabular}{lllllll}
\hline Değişken & N & Minimum & Maksimum & $\overline{\boldsymbol{X}}$ & Ss & Düzey \\
\hline $\begin{array}{l}\text { Dijital } \\
\text { Okuryazarlık }\end{array}$ & 847 & 1,71 & 5,00 & 3,96 & 0,58 & Yüksek \\
\hline
\end{tabular}

Tablo 8 incelendiğinde, ortaöğretim öğrencilerinin dijital okuryazarlık puanlarının 1,71 ile 5,00 arasında değiştiği anlaşılmaktadır. Ortaöğretim öğrencilerinin dijital okuryazarlık puan ortalaması 3,96 $(\mathrm{Ss}=0,58)$ olarak hesaplanmıştır. Elde edilen bu değer, araştırmaya katılan orta öğretim öğrencilerinin dijital okuryazarlık düzeylerinin yüksek olduğunu göstermiştir.

\subsection{Dördüncü Alt Probleme İlişkin Bulgular}

$\mathrm{Bu}$ bölümde "Ortaögretim öğrencilerinin dijital okuryazarlık düzeyleri; cinsiyetlerine, sinıf düzeylerine, internet kullanım yılına, günlük internette harcanan süre bakımından anlamlı bir farklılık göstermekte midir?" alt problemine ilişkin bulguya yer verilmiştir.

Tablo 9. Dijital Okuryazarlık Ölçeğinden Alınan Puanların Cinsiyete Göre Karşılaştırılması

\begin{tabular}{lllllll}
\hline Değişken & Cinsiyet & $\mathbf{N}$ & $\overline{\boldsymbol{X}}$ & Ss & $\mathbf{t}$ & $\mathbf{p}$ \\
\hline \multirow{2}{*}{ Dijital Okuryazarlık } & Erkek & 325 & 4,12 &, 58 & & \\
& K1z & 522 & 3,87 &, 55 & & \\
\hline
\end{tabular}

Tablo 9 incelendiğinde, ortaöğretim öğrencilerinin dijital okuryazarlık puan ortalamalarının cinsiyete göre farklılaşıp farklılaşmadığına ilişkin yapılan bağımsız gruplar t testi sonuçlarına göre istatistiksel olarak anlamlı bir farklılık gösterdiği anlaşılmaktadır $(\mathrm{p}<0,05)$. Cinsiyet ile dijital okuryazarlık arasında anlamlı bir ilişki bulunmaktadır. Araştırmaya katılan erkek öğrencilerin $\left(X^{-}=4,12\right)$ dijital okuryazarlık düzeyleri kız öğrencilerine $\left(\mathrm{X}^{-}=3,87\right)$ göre daha yüksek bulunmuştur. 
Tablo 10. Dijital Okuryazarlık Ölçeğinden Alınan Puanların Sınıf Düzeylerine Göre Karşılaştırılması

\begin{tabular}{|c|c|c|c|c|c|c|}
\hline Değişken & Sinıf & $\mathbf{N}$ & $\bar{X}$ & Ss & $\mathbf{F}$ & p \\
\hline \multirow{4}{*}{$\begin{array}{l}\text { Dijital } \\
\text { Okuryazarlık }\end{array}$} & 9. Sinıf & 294 & 4,00 &, 59 & \multirow{4}{*}{0,79} & \multirow{4}{*}{0,50} \\
\hline & 10. Sinif & 244 & 3,94 &, 54 & & \\
\hline & 11. Sinıf & 182 & 3,92 & ,60 & & \\
\hline & 12. Sinıf & 127 & 3,98 &, 58 & & \\
\hline
\end{tabular}

Tablo 10 incelendiğinde, ortaöğretim öğrencilerinin dijital okuryazarlık puan ortalamalarının sınıf düzeyine göre farklılaşıp farklılaşmadığına ilişkin yapılan Anova testi sonuçlarına göre gruplar arası anlamlı bir farklılık göstermediği anlaşılmaktadır $(p>0,05)$. Araştırmaya katılan 9, 10, 11 ve 12. sınıf öğrencilerinin dijital okuryazarlık düzeylerinin aynı olduğunu anlaşılmıştır.

Tablo 11. Dijital Okuryazarlık Ölçeğinden Alınan Puanların İnternet Kullanım Yılına Göre Karşılaştırılması

\begin{tabular}{|c|c|c|c|c|c|c|c|}
\hline Değişken & Yil & $\mathbf{N}$ & $\bar{X}$ & Ss & $\mathbf{F}$ & $\mathbf{p}$ & Fark \\
\hline \multirow{4}{*}{$\begin{array}{l}\text { Dijital } \\
\text { Okuryazarlık }\end{array}$} & 1 yildan az & 14 & 3,64 &, 73 & \multirow{4}{*}{14,19} & \multirow{4}{*}{0,00} & \multirow{4}{*}{$\begin{array}{l}4>1 \\
4>2 \\
4>3\end{array}$} \\
\hline & $1-2$ y1l & 61 & 3,80 &, 57 & & & \\
\hline & $2-5$ y1l & 283 & 3,83 &, 57 & & & \\
\hline & 5 yıldan fazla & 489 & 4,07 &, 56 & & & \\
\hline
\end{tabular}

Tablo 11 incelendiğinde, ortaöğretim öğrencilerinin dijital okuryazarlık puan ortalamalarının internet kullanım yılına göre farklılaşıp farklılaşmadığına ilişkin yapılan Anova testi sonuçlarına göre gruplar arası anlamlı bir farklılık gösterdiği anlaşılmaktadır $(\mathrm{p}<0,05)$. Grup farklılıklarının kaynağını belirlemek için Scheffe çoklu karşılaştırma testi kullanılmıştır. İnterneti "5 yıldan fazla" kullandığını belirten öğrencilerin dijital okuryazarlık düzeyleri, interneti "1 yıldan az", "1-2 yıl" ve "2-5 yll" kullandığını belirten öğrencilerinkinden anlamlı olarak daha yüksek bulunmuştur.

Tablo 12. Dijital Okuryazarlık Ölçeğinden Alınan Puanların Günlük İnternette Harcanan Süreye Göre Karşılaştırılması

\begin{tabular}{llllllll}
\hline Değişken & $\begin{array}{l}\text { Günlük internette } \\
\text { harcanan süre }\end{array}$ & $\mathbf{N}$ & $\overline{\boldsymbol{X}}$ & $\mathbf{S s}$ & $\mathbf{F}$ & $\mathbf{p}$ & Fark \\
& 1 saatten az & 94 & 3,81 &, 63 & & & \\
& $1-2$ saat & 310 & 3,90 &, 56 & & & $4>1$, \\
Dijital & $2-5$ saat & 350 & 4,01 &, 56 & & & $3>1 ;$ \\
Okuryazarlık & 5 saatten fazla & 93 & 4,15 &, 60 & & & \\
& & & &
\end{tabular}

16 | $\mathrm{P}$ a g e 
Tablo 12 incelendiğinde, ortaöğretim öğrencilerinin dijital okuryazarlık puan ortalamalarının günlük internette harcanan süreye göre farklılaşıp farklılaşmadığına ilişkin yapılan Anova testi sonuçlarına göre gruplar arası anlamlı bir farklılık gösterdiği anlaşılmaktadır $(\mathrm{p}<0,05)$. Günlük internette harcadığı süre "5 saatten fazla" olan öğrencilerin dijital okuryazarlık düzeyleri, günlük internette harcadığ 1 süre "1 saatten az" ve "1-2 saat" olan öğrencilerinkinden anlamlı olarak daha yüksektir. Ayrıca, günlük internette harcadığı süre "2-5 saat" olan öğrencilerin dijital okuryazarlık düzeyleri, günlük internette harcadığ 1 süre "1 saatten az" olan öğrencilerinkinden anlamlı olarak daha yüksek bulunmuştur. Genel olarak, günlük internette harcanan süre yükseldikçe dijital okuryazarlık düzeyinin de yükseldiği saptanmıştır.

\subsection{Beşinci Alt Probleme İlişkin Bulgular}

Bu bölümde "Ortaögretim öğrencilerinin dijital vatandaşlık düzeyleri ile dijital okuryazarlık düzeyleri arasında anlamlı bir ilişki var mıdır?” alt problemine ilişkin bulguya yer verilmiştir.

Tablo 13. Dijital Vatandaşlık ve Dijital Okuryazarlık Arasındaki İliş̧ki

\begin{tabular}{|c|c|c|c|c|c|}
\hline Değişkenler & $\overline{\mathbf{X}}$ & Ss & Sh & 1 & 2 \\
\hline 1. Dijital Vatandaşlık & 3,99 &, 44 & 0,01 & 1 &, $44^{* *}$ \\
\hline 2. Dijital Okuryazarlık & 3,96 &, 58 & 0,02 &, $44^{* *}$ & 1 \\
\hline
\end{tabular}

Tablo 12 incelendiğinde, dijital vatandaşlık puanları ile dijital okuryazarlık puanları arasında orta düzeyde pozitif yönlü ve istatistiksel olarak anlamlı bir ilişkinin bulunduğu anlaşılmaktadır $(r=0,44$; $\mathrm{p}<0,01)$. Ortaöğretim öğrencilerinin dijital vatandaşlık düzeyleri yükseldikçe dijital okuryazarlık düzeyinde de artı̧̧ göstermektedir.

\subsection{Altıncı Alt Probleme İlişskin Bulgular}

$\mathrm{Bu}$ bölümde "Dijital okuryazarlık dijital vatandaşlı̆̆ı yordayıcısı mıdır?" alt problemine ilişkin bulguya yer verilmiştir.

Tablo 13. Dijital Okuryazarlığın Dijital Vatandaşlık Üzerindeki Etkisini Belirlemek İçin Gerçekleştirilen Basit Doğrusal Regresyon Analizi Sonuçları

\begin{tabular}{llllll}
\hline Bağımsız Değişken & B & $\begin{array}{l}\text { Standart } \\
\text { Hata }\end{array}$ & $\boldsymbol{\beta}$ & $\mathbf{t}$ & $\mathbf{p}$ \\
\hline Sabit & 2,65 & 0,09 & & 28,05 & 0,000 \\
Dijital Okuryazarlık & 0,34 & 0,02 & 0,44 & 14,37 & 0,000 \\
$\mathrm{R}=0,443$ & $\mathrm{R}^{2}=0,196$ & & $\mathrm{~F}=206,35$ & & $p=0,00$ \\
\hline
\end{tabular}

Tablo 13 incelendiğinde, dijital okuryazarlığın dijital vatandaşlık üzerindeki etkisini belirlemek için geliştiren regresyon modeli istatistiksel olarak anlamlı bulunmuştur $(R=0,443 ; R 2=0,196 ; F=206,35$; $\mathrm{p}<0,001)$. Dijital okuryazarlık dijital vatandaşlık üzerinde pozitif yönlü ve istatistiksel olarak anlamlı bir etkiye sahiptir $(\beta=0,44 ; \mathrm{p}<0,01)$. Dijital okuryazarlık dijital vatandaşlıktaki değişimin yaklaşık \% 20'sini açıklamaktadır. Dijital okuryazarlık dijital vatandaşlık üzerinde önemli bir etkiye sahiptir. 


\section{Tartışma ve Sonuç}

Yapılan bu araştırmada ortaöğretim öğrencilerinin dijital vatandaşlık ve dijital okuryazarlık düzeyleri arasındaki ilişkinin çeşitli değişkenler açısından incelenerek, dijital okuryazarlık dijital vatandaşlığın yordayıcısı olup olmadığına bakılmışıtır.

Ortaöğretim öğrencilerinin dijital vatandaşlık düzeylerinin yüksek olduğunu saptanmıştır. Bu sonuç, ortaöğretim öğrencilerinin teknolojiyle iç içe olduğunu ve teknolojik araçları amacına uygun kullandığını göstermektedir. Bu durum alanyazında karşılaşılan diğer çalışmalarla (EREG, 2002; Kocadağ, 2012; Öztürk, 2015; Sakall1, 2015; Bakır, 2016; Aslan, 2016; Tatll, 2018) paralellik göstermesi dikkat çekmektedir. Ortaöğretim öğrencilerinin dijital vatandaşlık düzeylerinin cinsiyete göre anlamlı bir farklılık göstermediği saptanmıştır. Dijital vatandaş olma yolunda internet kullanımı önemli bir etkin olduğu düşünülmektedir. TÜiK (2018) raporlarına bakıldığında düzenli internet kullanım sıklığ erkeklerde \% 97,6 kadınlarda ise \% 96,8 olmuştur. Bu durum ortaöğretim öğrencilerinin dijital vatandaşlık düzeylerinin cinsiyet değişkinine göre farklılaşmadığını destekler niteliktedir. Ayrıca daha önce yapılan çalışmalar (Öztürk, 2015; Sakallı, 2015; Aslan, 2015; Tatlı, 2018) dijital vatandaşıı̆̆ı cinsiyet üzerinde etkisinin olmadığını göstermektedir. Ortaöğretim öğrencilerinin dijital vatandaşlık düzeylerinin sınıf düzeyine göre anlamlı bir farklılık göstermediği saptanmıştır. Ortaöğretim öğrencileri arasında sınıf düzeyleri gözetilmeksizin dijital vatandaşlık özelliklerini taşıdıkları söylenebilir. Yapılan benzer sonuçların (Öztürk, 2015; Sakallı, 2015; Aslan, 2016; Som-Vural, 2016; Çukurbaşı ve İşman, 2014) olması çalışmamızın sonucunu desteklemektedir. Ortaöğretim öğrencilerinin dijital vatandaşlık düzeylerinin internet kullanım yılına göre anlamlı bir farklılık gösterdiği saptanmıştır. İnterneti "1 - 2 yıl" ve "5 yıldan fazla" kullandığını belirten ortaöğretim öğrencilerin dijital vatandaşlık düzeyleri, interneti "1 yıldan az" kullandığını belirten ortaögretim öğrencilerinin dijital vatandaşlık düzeyleri anlamlı olarak daha yüksek olduğu sonucuna ulaşılmış̧ır. Bu sonuç öğrencilerinin internet kullanım yılı yükseldikçe dijital vatandaşlık tutumlarında artı̧ olduğunu (Çepni ve diğerleri, 2012) görüşünü destekler niteliktedir. Ortaöğretim öğrencilerinin dijital vatandaşlık düzeylerinin günlük internette harcanan süreye göre anlamlı bir farklılık göstermediği saptanmıştır. Elde edilen bu sonuç daha önce yapılan çalışma sonuçları $($ Sakallı, 2015) ile benzerlik göstermektedir.

Ortaöğretim öğrencilerinin dijital okuryazarlık düzeyinin yüksek olduğunu saptanmıştır. Bu durum ortaöğretim öğrencilerinin dijital ortamlarda sahip olması gereken becerilere sahip olduğu gösterebilir. Elde edilen bu sonuç daha önce yapılan çalışmaların sonuçları (Hatlevik, 2009; Tyger, 2011; Çetin, 2016; Kız11, 2017; Üstün ve diğerleri, 2017; Kozan, 2018; Tatll, 2018) ile benzerlik göstermektedir. Ortaögretim öğrencilerinin dijital okuryazarlık düzeylerinin cinsiyete göre anlamlı bir farklılık gösterdiği saptanmıştır. Araştırmaya katılan erkek öğrencilerinin dijital okuryazarlık düzeyleri kız öğrencilerin dijital okuryazarlık düzeylerinden daha yüksek olduğu saptanmıştır. Ayrıca daha önce yapılan çalışmalar (Çetin, 2016; Yeşildağ, 2018; Arık, 2018) dijital vatandaşlığın cinsiyet üzerinde etkisinin olduğunu göstermektedir. Ortaöğretim öğrencilerinin dijital okuryazarlık düzeylerinin sınıf düzeyine göre istatistiksel olarak anlamlı bir farklılık göstermediği saptanmıştı. Bu konuda yapılan çalışmaya bakıldığında Yıldız ve diğerleri (2012) ortaöğretim öğrencilerinin dijital okuryazarlık düzeylerinin öğrenim gördükleri sınıf düzeylerine göre istatistiksel olarak anlamlı olmadığını belirtmişlerdir. Ortaöğretim öğrencilerinin dijital okuryazarlık düzeylerinin internet kullanım yılına göre anlamlı bir farklılık gösterdiği saptanmıştır. İnterneti "5 yıldan fazla" kullandığını belirten ortaöğretim öğrencilerin dijital okuryazarlık düzeyleri, interneti "1 yıldan az", "1 - 2 yll” ve "2 - 5 yıl” kullandığını belirten öğrencilerin dijital okuryazarlık düzeyleri anlamlı olarak daha yüksek olduğu sonucuna ulaşılmıştır. Sonuç olarak, internet kullanım yılı yükseldikçe bireylerin dijital okuryazarlık düzeyinin de yükseldiği saptanmıştır. Bu durum alanyazında karşılaşılan diğer çalışmalarla (Çetin, 2016; Kozan, 2018) paralellik göstermesi dikkat çekmektedir. Ortaöğretim öğrencilerinin dijital okuryazarlık düzeylerinin günlük internette harcanan süreye göre anlamlı bir farklılı gösterdiği saptanmıştır. Genel olarak günlük internette harcanan süre fazlalaştıkça dijital okuryazarlık düzeylerinde artış saptanmıştır. Yapılan benzer sonuçların (Gündüz ve Özdünç, 2008; Hatlevik, 2009; Çetin, 2016) olması çalışmamızın sonucunu desteklemektedir.

Ortaöğretim öğrencilerinin dijital vatandaşlık düzeyleri ile dijital okuryazarlık düzeyleri arasında orta düzeyde pozitif bir korelasyon olduğu saptanmıştır. Bu sonuca göre, ortaöğretim öğrencilerinin dijital vatandaşlık düzeyleri yükseldikçe dijital okuryazarlık düzeylerinin de yükseldiği söylenebilir.

Dijital okuryazarlık, dijital vatandaşlık üzerinde pozitif yönlü ve istatistiksel olarak anlamlı bir etkiye sahiptir. Bu etki dijital vatandaşlı özelliklerinde, dijital okuryazarlığın önemli bir yordayısı olduğu düşünülebilir. Dijital okuryazarlık, dijital vatandaşlık üzerindeki değişimin yaklaşık \% 20'sını

18 | P a g e

www.iiste.org 
açıklamaktadır. Bu durum dijital okuryazarlığın dijital vatandaşlık üzerinde değişimin büyük olduğunu göstermektedir. Dijital okuryazarlık, dijital vatandaşlığın alt boyutlarından birisi (Ribble, 2011) olarak düşünüldüğünde dijital okuryazarlığın, dijital vatandaşlık üzerinde anlamlı bir etkiye sahip olduğunu destekler niteliktedir.

\section{Kaynaklar}

Akkoyunlu, B. ve Yılmaz, M. (2005). Öğretmen adaylarının bilgi okuryazarlı̆̆ı düzeyleri ile internet kullanım sıklıkları ve internet kullanım amaçları. Eğitim Araştırmaları, 5 (19), 1 - 14.

Prensky, M. (2001). Digital Natives, Digital Immigrants. From On the Horizon(MCB UniversityPress, Vol. 9 No. 5, October 2001).https://doi.org/10.1108/10748120110424816

TÜİK (2019). Hanehalkı Bilişim Teknolojileri Kullanımı Araştırma Sonuçları 08.03.2019 tarihinde http://www.tuik.gov.tr/PreHaberBultenleri.do?id=27819 adresinden erişildi.

Çubukçu, A. ve Bayzan, Ş. (2013). Türkiye'de dijital vatandaşlık algısı ve bu algıyı internetin bilinçli, güvenli ve etkin kullanımı ile artırma yöntemleri. Middle Eastern \& African Journal of Educational Research, 5, 148-173.

ISTE, (2007). Digital citizenship in schools. 12 Şubat 2017 tarihinde http://www.iste.org/ images/excerpts/digcit-excerpt.pdf adresinden edinilmiştir.

Ribble, M. (2007). Digital citizenship in schools. Eugene, OR: International Society forTechnology in Education.

Ribble, M. (2011). DigitalCitizenship in Schools, (Cilt 2nd Edition). Washington DC: The International SocietyforTechnology in Education (ISTE).

Hollandsworth, R., Donovan, J. ve Welch, M. (2017). Digital citizenship: you can't go home again. TechTrends, 1-7.https://doi.org/10.1007/s11528-017-0190-4

Check, J. ve Schutt, R. K. (2012). Research methods in education. Boston: Sage Publications. https://doi.org/10.4135/9781544307725

Karasar, N. (2011). Bilimsel Araştırma Yöntemi. Ankara: Nobel Yayın Dağıtım.

Büyüköztürk, Ş., Kılıç Çakmak, E., Akgün, Ö.E., Karadeniz, Ş. \& Demirel, F. (2016). Bilimsel araştırma yöntemleri (22. bask1).Ankara: Pegem Akademi. https://doi.org/10. 14527/ 9789944919289

Som Vural, S, Kurt, A . (2018). Üniversite Öğrencilerinin Bakış Açısıyla Dijital Vatandaşlık Göstergelerinin İncelenmesi. Eğitim Teknolojisi Kuram Ve Uygulama, 8 (1), 60 - 80 https://doi.org/10.17943/etku.317713 